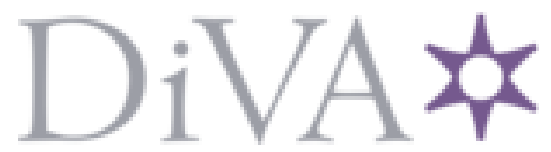

http://www.diva-portal.org

\title{
Postprint
}

This is the accepted version of a paper published in Scandinavian Journal of Occupational Therapy. This paper has been peer-reviewed but does not include the final publisher proof-corrections or journal pagination.

Citation for the original published paper (version of record):

Johansson, A., Björklund, A. (2015)

The impact of occupational therapy and lifestyle interventions on older persons' health, wellbeing, and occupational adaptation: A mixed-design study.

Scandinavian Journal of Occupational Therapy, 23(3): 207-219

http://dx.doi.org/10.3109/11038128.2015.1093544

Access to the published version may require subscription.

N.B. When citing this work, cite the original published paper.

Permanent link to this version:

http://urn.kb.se/resolve?urn=urn:nbn:se:hj:diva-28506 


\title{
The impact of occupational therapy and lifestyle interventions on older persons' health, well-being and occupational adaptation
}

\section{A mixed-design study}

\begin{abstract}
Aim: The aim of this study was to investigate if a four-month occupational based healthpromoting program for older persons living in community dwellings could maintain/improve their general health, and well-being. Further the aim was to explore if the program facilitated the older persons occupational adaptation. Methods: The study had a quasi-experimental design, with a non-equivalent control group combined with semi-structured interviews. The intervention group comprised 22 participants, and the control group 18. Outcomes were measured using the Short Form 36, Life Satisfaction Index-Z and Meaningful Activity Participation Assessment. Content analysis, based on concepts from the Model of Occupational Adaptation, was used to analyse the interviews. Results: The intervention group showed statistically significant improvements in general health variables such as vitality and mental health, and positive trends for psychological well-being. There were no statistically significant differences between the intervention group and the control group, but the groups was not fully matched. The qualitative analysis based on Occupational Adaptation pointed out social aspects as a compliment to the overall results. Conclusions: Participating in meaningful, challenging activities in different environments stimulates the occupational adaptation process; this is something occupational therapists could use to empower older persons to find their optimal occupational lives.
\end{abstract}

Key words:

activities of daily life, adaptive response, community dwellings, health promotion, Life Satisfaction Index-Z, mastery, Meaningful Activity Participation Assessment, primary care, SF-36, well-being 


\section{Introduction}

As we age our health declines, but there is a great deal that can be done to reduce, and adapt to, the consequences. It has been shown that small changes to the environment can mean a lot for older persons' independence and participation (1). This is in line with the World Health Organization's (WHO) policy framework Active Ageing, accentuating the importance of dignity, self-determination and influence, participation in working life and society, healthpromoting activities and independent living. Active aging is defined here as "the process of optimizing opportunities for health, participation and security in order to enhance quality of life as people age" (2). In Sweden, like in other European countries, the older population is growing fast. It is expected that by 2050, the percentage of the country's inhabitants over 65 years of age will have increased from today's $17 \%$ to about $25 \%$; the number of people over 85 years of age is expected to double by 2050 . This demographic development is becoming a huge challenge for society, with great demands on health and social care and concerning the individual's well-being (1). Primary care is responsible for the health of older persons, and it is now more important than ever to promote healthier and active aging, keeping in mind that older persons prefer programs that focus on health and independence, and to play an active role in deciding which activities to participate in (3). In the Ottawa Charter, WHO defines health promotion as "the process of enabling people to increase control over and to improve their health" (4). The Healthy Ageing project, initiated by the Swedish National Institute of Public Health in 2004-2007 and conducted in cooperation with other European countries and organizations, had the aim to promote healthy aging in later life $(50+)$. The project made recommendations to local authorities, practitioners, officials and non-governmental organizations (NGO), with special attention to "hard-to-reach" groups, work in partnership with older persons, academics and practitioners, and a reliance on evidence-based programs. A further recommendation was to create opportunities for older persons to have "regular physical activity, healthy eating habits, social relations and meaningful occupations" (p 32) 
(5). All these recommendations were considered when the current study was planned.

To have control over one's life is central for well-being (6). Well-being can be understood as subjective or psychological, whereby subjective well-being entails happiness and positive emotions. In addition to positive emotions it is essential to experience purpose and meaning, or psychological well-being - which includes areas such as self-acceptance, positive relationships, personal growth, purpose in life, autonomy and mastery (7). It has been shown that it is of great importance for older persons to have control over their life situation - to master their life. Additionally, higher levels of mastery (and perceived social support) were associated with lower levels of psychological suffering in both men and women aged 65 years and older (8).

The model of Occupational Adaptation (OA) (9-11) focuses on the concept of mastery and integrates the concepts of occupation and adaptation. Occupation is defined as an activity calling for active participation, which has meaning for the person and leads to a product. Adaptation is defined as the person's response when meeting an occupational challenge and demand from the environment, and occurs when the person's usual response is inadequate for mastering the activity. Engagement in meaningful activities enables an adaptive response and increases the individual's occupational performance. One of the main assumptions of OA is that the person has a desire to master activities and take control over the environment. In an earlier study, Johansson and Björklund (12) showed that OA was a suitable model for highlighting the importance of "just-right challenges" for an adaptive response for older persons living at home. OA presents a suitable conceptual model within the area of health promotion (13) in general, and was specifically chosen as a theoretical framework for this study.

Several researchers (14-17) have shown that older persons have the ability and need to adapt occupations and occupational patterns to manage their everyday life. It is also shown how 
important it is for older persons to use a broad repertoire of adaptive strategies to manage all their occupational challenges. The use of adaptive strategies increases the feeling of control, which leads to an increased feeling of health and well-being. The Life Style Redesign (LR) ${ }^{\circledR}$ program was an early attempt to intervene, in line with similar objectives (18).

The present intervention study is inspired by the (LR) ${ }^{\circledR}$ program (18), adapted to a local context and Swedish culture with support from Norwegian (19) and English research findings (20). The original LR ${ }^{\circledR}$ program was developed in connection with the Well Elderly Study (21-22), which showed reliable intervention effects according to physical and mental health, occupational functioning and quality of life. Additionally, a recent study, the Well Elderly II Trial (23), has shown that the program is applicable in reducing health decline and promotes well-being in older persons at high risk for poor health due to low socioeconomic status.

Even if the Well-elderly studies (21-23) indicated evidence for improved health and wellbeing, a systematic review shows weaker evidence for occupational performance (24). In a literature review concerning occupational therapy programs for health promotion Nilsson (25) found similar results. In addition to the Well-elderly studies (21-23) there are recent studies (26-29) that can be used in developing health promoting programs for community-dwelling older persons. Stav et al. (26) indicated strong evidence for the relationship between occupational engagement and health/well-being. Even if engagement in occupation has a strong link to health there could also be a risk of too much of engagement having a bad effect on health (27). A randomized controlled trial (28) was developed from the former English research findings (20). The trial will explore the clinical and cost effectiveness of the intervention and to support the policy maker's actions for implementation. In a Swedish study Zingmark et al. (29) compared three different occupation-focused interventions; individual, activity group and one-meeting discussion group with a control group. The results showed that both individual and group interventions had some positive, but small effects. The 
authors raised the question which format is optimal for best intervention effects for well older persons. Zingmark et al. used individual or group interventions where other studies used a combination of both $(21,23)$.

The aim of this study was to investigate if a four-month occupational based health-promoting program for older persons living in community dwellings could maintain/improve their general health and well-being. Further the aim was to explore if the program facilitated the older persons occupational adaptation.

\section{Material and methods}

\section{Study design}

A pilot study (30) preceded this main study in order to develop and try out the healthpromoting program. After the pilot was evaluated, the inclusion criteria for the main study were changed for the purpose of reaching a somewhat younger group and with less need of care. According to the aim of the study some of the research instruments were also exchanged for the purpose to strengthen the quality of measuring wellbeing.

The first Well Elderly Study was conducted for a period of nine months, and the second for six months. For adapting the program to a Swedish context and usability in primary care the present study was conducted for a period of four months. LR ${ }^{\circledR}$ programs have mostly been conducted in an American context and partly in English and Norwegian ones, but, to our knowledge, never in a Swedish context. The recruitment process was obstructed because of insufficient access to participants and a quasi-experimental design with a non-equivalent control group, using pre-tests and post-tests, was consequently preferable (31). This design was combined with semi-structured interviews with the participants in the intervention group (32). The combination of quantitative and qualitative methods for the collection of data, a mixed design, was used in order to triangulate the data sources and to study the intervention 
from different perspectives. Our intension with this design was that the qualitative data material should validate the quantitative and give a deeper understanding of the results.

The study was approved by the Committee of Research Ethics in Linköping, Sweden (Dnr: 166-07). The main research ethical demands for information, consent, confidentiality and use were maintained (33). Presumptive participants were informed verbally about the study first by their occupational therapist and then through a written document from the authors, which they were to sign to give informed consent if they agreed to participate in the study.

\section{Participants}

As a result of a power analysis, with a required power of $80 \%$ and $p \leq 0.05$, based on previous measures with SF-36 where SD in average was around 23.86 on a 100 degree scale, and an assumption that a change on at least 11 scale step is clinical relevant, a total of 50 participants were needed i.e. 25 in each group (34).

The inclusion criteria for the main study were that the participants in the intervention group had to be over 65 years of age, live in a community dwelling and have no homecare. The control group met the same inclusion criteria, and the groups were matched by gender and age.

The participants in the intervention group were recruited through convenience sampling from a coherent geographic housing area, comprising apartments in an urban environment. The occupational therapists and the social worker in the primary care district asked older persons whom they believed could benefit from the program to participate in the study. The participants in the control group were recruited from another primary care district but with a similar urban environment, and were asked to participate by their occupational therapist. The 
recruitment process is illustrated in Figure 1.

\section{Insert Figure 1}

The intervention group contained 22 participants with a mean age of 82 years, and the control group 18 participants with a mean age of 81 years. The participants in the intervention group were mostly women living alone, suffering from different chronic conditions but with a predominance of orthopaedic problems. The intervention group had a higher number of previous blue-collar workers than the control group (Table 1).

\section{Insert Table 1}

\section{Procedure}

Intervention group

During the period 2010-2012, three groups of older people (Figure 1) were given healthpromoting interventions for two hours per week for four months, as well as a maximum of four hours of individual interventions. The groups were facilitated by two occupational therapists from primary care in the county council. Before the program started the facilitators were provided training by a lecturer in occupational therapy (the first author), who also continuously supervised the facilitator. Each participant was paid a home visit and a needs assessment in the form of an interview, conducted in order to develop the program based on each participant's need for meaningful and challenging occupations. The questions elucidated what the participants preferred to do in the past as well as now and what they wished to do, and whether there were any obstacles to doing this.

The program was presented to the participants, and each group selected the themes and topics they wanted to work with as well as what they considered enough meaningful and 
challenging. The groups met at a place in the community, which was especially important since the program aimed to be health-promoting and not a healthcare program. The overall aim of the program was to give the older persons the opportunity to reflect on their own occupational lives and become aware of ways they could see to their general health, wellbeing and independence in activities for daily living.

Each session started with information or a lecture on "today's theme", followed by group discussion and exchange of experiences, and ended with a suitable activity related to "today's theme", sometimes carried out in the community. The themes were Occupation, health and aging; Occupation, time and energy; Occupation and mobility; Eating as an occupation; Physical activity as an occupation; Occupation and mental well-being; Occupation and security at home and in the society; Occupation and relationships; Occupation and economy; and Occupation and technical devices. The participants were encouraged to reflect over the content of each theme and what it meant to them. At a follow-up home visit, the occupational therapist supported the participants in exploring and adapting the knowledge from the group sessions into their daily life.

\section{Control group}

The control group received occasional occupational therapy interventions from an occupational therapist at their primary care district, for example prescription of assistive devices, but did not take part in any group interventions.

\section{Data collection}

\section{Quantitative measures}

Outcomes were measured using the Short Form 36 (SF-36), Life Satisfaction Index-Z (LSI-Z) and Meaningful Activity Participation Assessment (MAPA) at baseline and four-month follow-up. In addition, at four-month follow-up a semi-structured interview with the 
intervention group divided into smaller groups was conducted. For the control group, data were collected at baseline and after a period of four months.

The SF-36 was used to measure self-experienced general health. This valid and reliable instrument consists of 36 questions in eight dimensions: physical functioning, role-physical, bodily pain, general health, vitality, social functioning, role-emotional and mental health (35). The instrument is appropriate for use with older persons, and for most participants in this study it was used as an interview (36).

The individual perception of psychological well-being was measured using the LSI-Z (37), an instrument commonly used with older persons. The instrument reflects zest for life, resolution and fortitude, congruence between desired and achieved goals, positive self-concept and optimistic mood. Examples of the statements participants were asked to assess include: "These are the best years of my life" and "Compared to other people, I feel down in the dumps too often". The assessment is based on 13 questions ranked on a five-point scale, like in Berg et al. (38), to which is more detailed than the original scale. The total score ranged from 13-65, with a higher score indicating higher perceived life satisfaction.

The SF-36 and LSI-Z were used because of their strength as outcome measures in the Well Elderly Studies I and II $(21,23)$, and for their reliability and validity. The MAPA (39) is a 28item tool for measuring meaningfulness of activity, and has been tested with elderly persons (40). Subjects indicate frequency of participation and the degree of meaningfulness for each activity. The possible score range is $0-672$, with a higher score indicating greater meaningful activity participation. The MAPA was used because it is a reliable and valid measure of meaningful activity, and as showed in Eakman, Carlsson and Clark (40) it has a strong relation with psychological well-being. With permission from the author of the assessment, it was translated into Swedish by the first author. 
Qualitative group interviews

In addition to the quantitative measures, the intervention groups were interviewed in six groups containing two to four participants each. With four external dropouts due to summer trips, the group was comprised of 18 participants in total. The semi-structured interviews were held after the intervention period, and were conducted with support from an interview guide containing the following questions: Tell me how you have experienced the program. Has the program had any impact on your daily activities? If so, in what way? Has the program had any impact on your thoughts and feelings about yourself as an active person? If so, in what way? Has the program had any impact on your social contacts and activities in the society? If so, in what way? The aim was to record experiences of the program and how the participants had used achieved knowledge (changes and/or adaptations in daily life) and strategies learnt from the program

\section{Data analysis}

\section{Quantitative measures}

The statistical analysis was done using the SPSS Statistical package for the Social Sciences, version 19. T-test was used for SF-36 to test differences pre-and post-intervention and differences between intervention and control group. In line with tradition, the SF-36 data are analysed parametric even if the questions are of ordinal type (41). According to LSI-Z and MAPA the Wilcoxon signed-ranks test were used to test differences pre- and postintervention and the Mann-Whitney U-test was used to test differences between the intervention and control groups.

The level of significance was set to $p<0.05$.

\section{Qualitative group interviews}

Qualitative content analysis (42) with a deductive approach (43) was used for the analysis of the data from the semi-structured group interviews. This means that concepts within the 
chosen theoretical framework, in this case the model of Occupational Adaptation (9-11), were used as "content areas" in answering how the health-promoting program had impacted the participants' adaptation of activities for daily living. The following concepts were used as content areas in the analysis procedure: Desire for mastery - Since the earliest part of childhood the human being has a desire to master activities, and this desire lasts throughout life. The person's genetic, environmental and phenomenological factors contribute to his/her unique capabilities; The Occupational environmental demand for mastery - An occupational environment consists of a complicated system of external stimuli that call for a masterful response. Each occupational environment entails expectations and has an impact on the person and his/her occupational performance. Each occupational environment is affected by the physical (time and space), social (interpersonal interaction and social leadership) and cultural (values, rules and communication methods) factors that are parts of the person's unique context; The adaptive response - The person's desire and environmental demands for mastery interact to produce a press for mastery or an adaptive response. This adaptive response is an internal mechanism that the individual activates to create a plan for action that responds to an occupational challenge. In this study, the participants' adaptive responses , are in direct relation to the program's overall aim of giving elderly people the opportunity to reflect on their own occupational lives and become aware of ways they could see to their general health, well-being and activities for daily living. The analysis was performed in six steps: 1) the interviews were read through several times to get an overview of the whole content. Text belonging to the content areas Desire for mastery, The Occupational environmental demand for mastery, and Adaptive response was collected into one text with separate sections. Meaning units from the content areas were underlined, and irrelevant text was deleted; 2) The meaning units were condensed into shorter sentences closely resembling the original text in each of the content areas ; 3) The condensed meaning units in each content 
area were further abstracted into codes; 4) The codes were compared based on similarities and divergences, and were then grouped into subcategories; 5) The subcategories from each content area were compared with each other and compiled into categories. Each category was named with reference to Desire for mastery (Independence), Occupational environmental demand for mastery (Belonging to a group and Self-esteem) and Adaptive response (Change in occupational behaviour and Change in occupational approach); 6) The five categories were further abstracted to a theme called Maintaining activities of daily living (42). Examples of meaning units, condensed meaning units, codes, subcategories, categories and theme are shown in Table 2.

\section{Insert Table 2}

\section{Results}

The results are structured in two parts: firstly, the results from the quantitative measures SF36, LSI-Z and MAPA are accounted for and thereafter, the results from the group interviews are presented in relation to concepts from the Model of Occupational Adaptation.

\section{Self-experienced general health and well-being}

A Mann-Whitney U-test was run to determine if there were baseline differences between the intervention- and the control groups, according to SF-36 subscales, and it showed no significant differences $(P>0.01)$. At four-month follow-up, five of eight SF-36 subscales (physical functioning, bodily pain, general health, vitality and mental health) showed a positive change within the intervention group. Vitality $(P=0.01)$ and mental health $(P=0.03)$ showed significant change. The subscales role-physical, social functioning and role-emotional showed a positive change, albeit not significant, within the control group. There had been no statistically significant differences in the comparisons between the intervention group and the control group at four-month follow-up in any of the SF-36 subscales (2-tailed) nor in the 
physical and mental composite (Table 3).

\section{Insert Table 3}

The MAPA showed a positive change within the intervention group at four-month follow-up, and the results were close to statistically significant. The control group showed a negative change. There were no statistically significant differences between the intervention group and the control group (Table 4). Results from the LSI-Z had deteriorated both within the intervention group and within the control group at four-month follow-up, but there was less negative change in the intervention group. There were no statistically significant differences between the intervention group and the control group (Table 4).

\section{Insert Table 4}

\section{Occupational adaptation}

The results of the qualitative data analysis are structured in relation to the five subordinate categories Independence, Belonging to a group, Self-esteem, Change in occupational behaviour and Change in occupational approach. (Fig.1).The results are further illustrated with quotations from participants in the group interviews and are marked, for example $(P 1)$, meaning Participant 1.

\section{Independence}

The participants described how important it is to be independent, and to be able to manage the things they want and need to do. They also described the negative feeling of other people's attitudes, seeing them as old and no longer capable. The participants stressed a need to manage the things they used to do and to show other people that they, even at a high age, are capable persons: 
For me it's very difficult to ask for help because I want to be independent ... maybe it's wrong...but I have a need ... to feel I can manage (P 15).

\section{Belonging to a group}

The participants emphasized the importance of having a goal for the day, and how the group meetings gave their week structure and a weekly routine. The meetings were a reason to get up and around in the morning, be on time and get out of the home. It was also important for the participants to have a reason to take the stairs from their apartment and to take a walk, to and from the meetings.

I may say it was a nice feeling every Friday when I went again...this makes me go out for a walk early in the morning... which I wouldn't have done otherwise (P 6).

According to the participants the group meetings had an important social meaning. The meetings created a social community where the atmosphere was cheerful and positive. The participants enjoyed each other and, together with the facilitators, built up a strong community. This placed a positive press on them to not miss a group meeting and to contribute to the community. The participants also had hopes to maintain their new friendships and to be part of a new social network.

It would've been nice if we didn't just drop it but built these further...that would be meaningful for me (P 9).

The participants shared experiences about problems in everyday life and how they had found solutions. They described how important it is to hear about experiences and get tips from persons of their own age and in a similar social situation.

You're sitting in a group and share a lot of different things and you get important tips...we shared...one person said this and the other said that (P 1). 
The group had, in an implicit way, found rules for their communication. The conversation attitude was warm, and there was a great deal of laughter. The participants avoided speaking about diseases and ailment, which was perceived as very positive.

We've met and have had a very nice time together, and everybody has been so positive, and with no grouching (P 13).

\section{Self esteem}

The participants emphasized how important the facilitators' attitude and treatment had been. They described how they had gotten better self-esteem through the group meetings, where they were listened to and valued despite their high age. They felt uplifted and important, and described how they had gained insight into how important their experiences could be to others:

We have learnt that you're not worthless when you're old and we've figured out that we can do a lot of things and such, and this was very nice. To be sure, we were really uplifted (P 16).

\section{Change in occupational behaviour}

The participants gave concrete and practical examples of adaptive strategies for everyday life. Many of the strategies and adaptive behaviour concerned safety at home and fall prevention. The adaptive strategies also concerned not only possibilities to exercise and keep fit, but also managing to get up from the floor in case of a fall:

You should have anti-skid protection under your rugs, and not climb on chairs, and things you use often shouldn't be high up in the cupboards (P 1). 
The strategies also dealt with managing their occupations and challenges in society. By calling attention to their needs as an older person and placing demands on their surroundings, the participants felt safer and more secure in different situations:

About taking the bus...I used to be afraid...I was very afraid...the drivers don't wait until you've sat down...but I was told to tell them to wait...so now I dare to take the bus again (P 15).

\section{Change in occupational approach}

The participants gave examples of how they had adapted their approach and thoughts about themselves as an active person. They had gained knowledge about the importance of everyday life activities and realized the connection between what you do/how you do it and your health:

Especially in the winter when you're a bit disabled like me, and when the snowclearing has been bad it's not easy to get out for a walk...so then I had in the back of my head...yes, I do a great deal at home... and it was nice to get it confirmed that you shouldn't despise these things you do at home (P 9).

\section{Discussion}

This study showed positive trends within the intervention group, even if it did not show statistically significant differences between the intervention group and the control group. This may have several explanations. While our program was inspired by LR ${ }^{\circledR}$, the original LR program was not fully replicated. Our program ran over four months, instead of nine (21) or six months (23). The demographics of the participants differed, with a higher mean age in our program compared to the Well-elderly studies (21-23); also, our program had no ethnic diversity. The control group was not fully matched to the intervention group. An explanation for this will follow below. 
The quantitative data at four-month follow-up for the intervention group showed statistically significant improvements in general health variables such as vitality and mental health, as also seen in the Well Elderly Study II (23). The results showed that the intervention seems to have more impact on the well-being aspects than the physical ones. The data also showed positive trends for the intervention group in the case of psychological well-being, measured by using the MAPA, and the results were close to significant. The results from the LSI-Z showed negative results at four-month follow-up, and are not comparable with results from former studies $(21,23)$ as we used a five-point scale instead of a three-point one.

This study also showed that the program facilitated the participant's occupational adaptation. The participants had a need to control their lives, to master life and to be independent. The program, the group meetings and the facilitators composed a positive occupational environmental demand on the participants, including both physical and social factors. Our study showed that being a member of a group gives you positive relationships, selfacceptance and personal growth, and has a huge impact on how you adapt your abilities to manage time, space and social interactions. Sharing experiences from everyday life with people your own age was important for the participants, as also confirmed by Mountain et al. (20) and Mountain (44). According to Williams and Murray (45), humour seems to be an important strategy for facilitating occupational mastery and social life, and this was a strategy often used within the group. The results of our study indicate that the participants valued being treated with dignity, being seen and being heard. These are important factors for healthy aging, which was also shown in a recent study from Gothenburg (46). Our study showed that the program facilitated the participant's occupational adaptation when they learned new things about occupational performance and change in occupational approach, which had an impact on their perceptions of themselves as occupational beings. Participating in meaningful challenging activities in different environments stimulates the occupational adaptation process 
$(10-11,14)$ this is something occupational therapists could use to empower older persons in finding their optimal occupational lives (16).

The study has some limitations, which could have affected the results. The sample size is small and we didn't reach 50 participants as the power calculation indicated. A smaller sample size and lower power could be a threat to the statistical conclusion validity (47). In relation to our results and as a consequence it could have been concluded that there is no relationship even if it is in reality. A strong qualitative evaluation doesn't change the lack of power but gives an additional view and deepen our understanding of the quantitative results that may strengthen the overall validity of the study. To avoid the above mentioned limitations we should strive for RCTs with larger amount of participants even if it's a huge challenge to conduct such research among vulnerable populations as older people (48). The program had mostly female participants and this accords with s the tendency in several group intervention studies $(20,23,29)$. Participants in this study were recruited from a primary care district and with support from health care staff. An explanation to this skewed recruitment is that women in Sweden live 4.6 years longer and are visiting healthcare more often than men (49). This means that there are more women available for recruitment via primary care contexts. Probably men have to be found in other contexts which are a challenge in itself and subject for further studies".

The MAPA (39) was translated into Swedish for the purpose of this study, and has not been validated in larger Swedish populations. Some of the expressions in the assessment were difficult to translate into words that carried the same meaning in the Swedish context and for Swedish elderly persons. It was also difficult for the participants to score how important an activity was. The control group met the same inclusion criteria as the intervention group, and was matched by gender and age, but was from another primary care district with a similar urban environment. The participants were matched by age and gender but not by socio- 
economic situation or former job/profession, which meant that the characteristics of the groups were not completely alike. Several participants in the control group lived with a spouse, and this group contained a higher number of white-collar professions. A similar trend was shown for chronic conditions, with the control group having 1.8 mentioned diseases compared to 2.6 in the intervention group (Table 1). It is known that socioeconomic factors in living conditions continue after retirement. Additionally, poor health, pain condition, mobility and psychological problems are more common among elderly persons with a blue-collar worker background than in those with a white-collar background (50). The qualitative data were analysed with a deductive approach (43), with the model of Occupational Adaptation used as a theoretical framework. Although the theory is informed the analysis could be biased, since it might be easier to find data that support the theory than those that do not. How should we measure results for health promotion activities with older persons? It poses a problem to find the best suitable measurements which are sensitive enough to find important outcomes for older person. Mountain et al. (20) found SF-36 sensitive enough for measuring changes in general health conditions and so did our study. When it comes to functional measures we must also take into consideration that the natural aging process may have an impact on the results (6). Many health promoting studies within occupational therapy show evident results for health and well-being but weaker results or have no measures for occupational performance at all (24-25). Maybe this is an indicator for the lack of suitable measurements that captures the most important aspects of occupational performance in old age.

This study had a mixed design, with both quantitative and qualitative methods. The triangulation could be one method for getting several perspectives from the intervention and obtaining as useful results as possible

This study shows that a health promotion program, inspired by the LR® program and adapted to a Swedish context, is a useful method for older community-dwelling persons. A 
period of four months is practicable for the Swedish context, but the results could probably increase with a longer time period. This study also brings up the question of whether, in comparison with a recent study (23), we have reached the groups with the highest risk for illhealth; for example older persons with low education and/or low income or with other ethnicities than Swedish (6)? We suggest further research in order to reach the older persons who have the highest risk of unhealthy living conditions, and to find culturally applicable interventions for this group.

\section{Conclusions}

This study showed that a four-month occupational based health-promotion program, led by occupational therapists, improved older persons' self-experienced health, vitality, mental health and their sense of psychological well-being. Even if the study showed positive trends within the intervention group, there were no statistically significant changes in selfexperienced health and well-being between the intervention group and the control group, but the groups were not fully matched. The qualitative analysis based on Occupational Adaptation pointed out other important aspects as a compliment to the overall results. The group meetings had an important social meaning which gave the participants a preferable weekly routine. The content of the program and the peer exchange gave the participants strategies to manage everyday life at home and in society. The facilitators had an unexpected important role by increasing the participants' self-esteem and personal growth which strengthened their thoughts about themselves as a capable person. To conclude, participating in meaningful, challenging group activities in different environments stimulates the occupational adaptation process; this is something occupational therapists could use to empower older persons to find their optimal occupational lives. 


\section{Acknowledgements}

The authors would like to give special thanks to the occupational therapist Catarina Broman, who participated throughout the study, as well as to the occupational therapists Gunlög Ingolf and Cecilia Andersson (Hälsans medical center 1, Jönköpings County Council), who contributed to this research with their time and knowledge. Thanks also to Dr. David Rusaw (Department of Rehabilitation, School of Health and Welfare, Jönköping University) for his advice on statistics. 


\section{References}

1. Ministry of Health and Social Affairs. Europeiska året Aktivt åldrande och solidaritet mellan generationer 2012 [European Year Active Aging and Solidarity between generations 2012]. Stockholm: Ministry of Health and Social Affairs; 2011. In Swedish. [Cited 2013 Dec 8]. Available from: http://www.regeringen.se/content/1/c6/18/21/18/8a89c946.pdf

2. World Health Organization. (WHO). Active Aging. A policy framework. Geneva: WHO; 2002.

3. Boeckxstaens P, De Graaf P. Primary care and care for older persons: Position paper of the European forum for primary care. Qual Prim Care 2011; 19: 369-389.

4. World Health Organization. (WHO). The Ottawa charter for health promotion 1986. Geneva: WHO; 2013. [Cited 2013 Dec 8]. Available from:

http://www.who.int/healthpromotion/conferences/previous/ottawa/en/index.html

5. Swedish National Institute of Public Health. Healthy Aging in Europe-lessons learnt and ways forward. Stockholm: Swedish National Institute of Public Health distribution; 2009.

6. Swedish National Institute of Public Health. Hälsoutveckling och hälsofrämjande insatser på äldre dar. Health development and health promoting effort in old age (summary in English).Stockholm: Statens Folkhälsoinstitut; 2005. [Cited 2013 Dec 8]. Available from: http://www.fhi.se/PageFiles/3968/r20056Aldredar0505.pdf

7. Berg AI. Life satisfaction in late life: markers and predictors of level and change among 80+ year olds. [Dissertation]. University of Gothenburg; 2008.

8. Gadalla TM. The role of mastery and social support in the association between life stressors and psychological distress in older Canadians. J Gerontol Soc Work 2010; 53: 512530.

9. Schkade JK, Shultz S. Occupational Adaptation: Toward a holistic approach for contemporary practice, part 1. Am J Occup Ther 1992; 829- 837.

10. Shultz S, Schkade JK. Occupational Adaptation: Toward a holistic approach for contemporary practice, part 2. Am J Occup Ther 1992; 917- 925.

11. Schultz S, Schkade J. Adaptation: Modifying the person/environment transaction in Christianson, C. \& Baum, C. (Eds.) Occupational Therapy: Enabling Function and Well Being (2nd Ed.). Thorafare: N. J. Slack, Inc; 1997.

12. Johansson A, Björklund A. Occupational adaptation or well-tried, professional experience in rehabilitation of the disabled elderly at home. Act Adapt Aging 2006; 30: 1 - 21 .

13. Scaffa ME, Reitz SM, Pizzi MA. Occupational therapy in the promotion of health and wellness. Philadelphia: F.A. David Company; 2010. 
14. Clark F, Carlson M, Zemke R, Frank G, Patterson K, Ennevor BL, Rankin-Martine A, Hobson L, Crandall J, Mandel D, Lipson L. Life domains and adaptive strategies of a group of low- income, well older adults. Am J Occup Ther 1996; 50: 99- 108.

15. Hocking C, Murphy J, Reed K. Strategies older New Zealanders use to participate in dayto-day occupations. Br J Occup Ther 2011; 74: 509-516.

16. Thorén Jönsson AL, Möller A, Grimby G. Managing occupations in everyday life to achieve adaptation. Am J Occup Ther 1999; 53: 353- 362.

17. Bontje P, Kinébanian A, Josephsson S, Tamura Y. Occupational adaptation: The experiences of older persons with physical disabilities. Am J Occup Ther 2004; 58:140-149.

18. Mandel DR, Jackson JM, Zemke R, Nelson, L. Clark, FA. Lifestyle Redesign, Implementing the Well Elderly Program. Bethesda: The American Occupational Association; 1999.

19. Svendsen LK, Otterholt Lillebø M. Aktivitet og Livsstil. Livsstilsprogram- enn helsefremmende og forebyggande metode.(Occupation and lifestyle. Lifestyle program-a method in health promotion and prevention. (In Norwegian). Oslo: Stiftelsen Kirkens Bymisjon; 2007.

20. Mountain G, Mozley C, Craig C, Ball L. Occupational therapy led health promotion for older people: Feasibility of the lifestyle matters program. Br J Occup Ther 2008; 71: 406-413.

21. Clark F, Azen SP, Zemke R, Jackson J, Carlson M, Mandel D, et al. Occupational Therapy for Independent-Living Older Adults, A Randomized Controlled trial. JAMA 1997; 278: $1321-1326$.

22. Jackson J, Carlson M, Mandel D, Zemke R, Clark F. Occupation in lifestyle redesign: The well elderly study Occupational Therapy program. Am J Occup Ther 1998; 52: 326-336.

23. Clark F, Jackson J, Carlsson M, Chou CP, Cherry BJ, Jordan -Marsh M, et al. Effectiveness of a lifestyle intervention in promoting the well-being of independently living older people: results of the Well Elderly 2 randomized controlled trial. J Epidemiol Community Health 2012; 66: 782-790.

24. Orellano E, Colón WI, Arbesman M. Effect of occupation and activity-based interventions on instrumental activities of daily living performance among community-dwelling older adults: a systematic review. Am J Occup Ther 2012; 66: 292-300.

25. Nilsson I. Aktivitetsbaserade hälsofrämjande insatser för äldre. (Activity-based health promotion interventions for older people). In Swedish. Tidskriften Arbetsterapeuten 2013; $8 / 13$. 
26. Stav WB, Hallenen T, Lane J, Arbesman M. Systematic review of occupational engagement and health outcomes among community-dwelling older adults. Am J Occup Ther 2012; 66: 301-310.

27. Moll SE, Gewurtz RE, Krupa TM, Law MC. (2013). Promoting an occupational perspective in public health. Can J Occup Ther 2013 80: 111.

28. Sprange K, Mountain GA, Brazier J, Cook SP, Craig C, Hind D, Walters SJ, Windle G, Woods R, Keetharuth AD, Chater T, Horner K. Lifestyle Matters for maintenance of health and wellbeing in people aged 65 years and over: study protocol for a randomised controlled trial. Trials $2013 ; 14: 302$.

29. Zingmark M, Fisher AG, Rocklöv J, Nilsson I. Occupation-focused interventions for well older people: An exploratory randomized controlled trial.

Scand J Occup Ther 2014; 21: 447-45.

30. Johansson A. Aktivt liv på äldre dar - ett pilotprojekt för att pröva ett aktivitetsfokuserat program. [Active life in the elderly]. Jönköping: Luppen Kunskapscentrum: FoU-rapport. In Swedish. 2009:1; ÄO Äldreomsorg och äldrevård.

31. De Poy E, Gitlin N. Introduction to research. Understanding and applying multiple strategies. 3ed. Missouri: Elsevier Mosby; 2005

32. Stewart DW, Shamdasani PN, Rook DW. Focus Groups - Theory and Practice. Second Edition. California: Sage Publication, Inc; 2007.

33. World Medical Association. (WMA). Declaration of Helsinki - Ethical Principles for Medical Research Involving Human Subjects. 2013. Available at:

http://www.wma.net/en/30publications/10policies/b3/index.html 7 th December 2013.

34. Streiner DL, Norman GR. Health measurement scales: a practical guide to their development and use.3.ed. Oxford: Oxford University Press; 2003.

35. Sullivan M, Karlsson J, Taft C, Ware JE. SF-36 Hälsoenkät: Svensk Manual och Tolkningsguide, 2:a upplagan (Swedish Manual and Interpretation Guide, 2nd Edition). Gothenburg: Sahlgrenska University Hospital, 2002.

36. Hayes SV, Morris J, Wolfe C, Morgan M. The SF-36 health survey questionnaire: is it suitable for use with older adults? Age Ageing 1995; 24:120-125.

37. Wood V, Wylie ML, Sheafor B. An analysis of a short self-report measure of life satisfaction: Correlation with rater judgments. J Gerontol 1969; 24: 465-469.

38. Berg IA, Hassin LB, Mc Clearn GE, Johansson B. What matters for life satisfaction in the oldest-old? Aging Ment Health 2006; 10: 257-264.

39. Eakman AM. A reliability and validity study of the meaningful activity participation assessment. Ann Arbor, MI: University Microfilms International; 2007. 
40. Eakman AM, Carlsson ME, Clark FA. The meaningful activity participation assessment: a measure of engagement in personally valued activities. Int J Aging Hum Dev 2010; 70: 299317.

41. Wright BD, Linacre JM. Observations are always ordinal; measurements, however, must be interval. Archives of Physical Medicine and Rehabilitation 1989; 70, 857-860.

42. Graneheim U, Lundman B. Qualitative content analysis in nursing research: concepts, procedures and measures to achieve trustworthiness. Nurse Educ Today 2004; 24: 5- 12.

43. Hsieh HF, Shannon SE. Three approaches to qualitative content analysis. Qual Health Res 2005; 15: 1277-1288.

44. Mountain GA. The lived experience of redesigning lifestyle post-retirement in the UK. Occup Ther Int 2010; 18: 48-58.

45. Williams S, Murray C. The lived experience of older adults'occupational adaptation following a stroke. Austr Occup Ther J 2013; 60: 39-47.

46. Hörder HM, Frändin K, Larsson, MEH. Self-respect through ability to keep fear of frailty at a distance: Successful ageing from the perspective of community-dwelling older people. Int J Qual Stud Health Well-Being 2013; 8: 1-14.

47. Kazdin AE. .Research design in clinical psychology. (4ed). Boston: Allyon \& Bacon; 2002.

48. Pyatak EA, Blanche EI, Garber SL, Diaz J, Blanchard J, Florindez, L, Clark FA. Conducting intervention research among underserved populations: lessons learned and recommendations for researchers. Archives of Physical Medicine and Rehabilitation 2013; 94:1190-8.

49. The National Board of Health and Welfare. (2004). Jämställd vård? - Könsperspektiv på hälso -och sjukvården. [Equal care? - Gender perspective in healthcare]. In Swedish. [Cited 2015 April 25]. Available from: http://www.socialstyrelsen.se/publikationer2004/2004-103-3

50. Elderly people's health: Health in Sweden: The National Public Health Report 2012. Chapter 5 Carin Lennartsson and Inger Heimerson. Scand J Public Health 2012; 40: 95-120. 
Table 1: Demographics characteristics of the total sample $(n=40)$.

\begin{tabular}{lll}
\hline Variable & $\begin{array}{l}\text { Intervention } \\
\text { group } \\
(\mathrm{n}=22)\end{array}$ & $\begin{array}{l}\text { Control } \\
\text { group } \\
(\mathrm{n}=18)\end{array}$ \\
\hline Mean age & 82 & 81 \\
$\begin{array}{l}\text { Min-max } \\
\text { Gender }\end{array}$ & $76-89$ & $72-92$ \\
Female & 21 & 17 \\
Male & 1 & 1 \\
Social situation & & 8 \\
Living alone & 21 & 10 \\
Living with a spouse & 1 & 3 \\
Former job/profession & & 13 \\
Blue-collar worker & 12 & 2 \\
White-collar worker & 9 & \\
Enterpriser & 1 & 8 \\
No paid work & & 4 \\
Chronic conditions & & 1 \\
Orthopedic problem & & 1 \\
Heart and vessel disorder & 14 & 2 \\
Stroke & 6 & 1 \\
Diabetes & & 1.8 \\
Vertigo & 1 & \\
Depression & 1 & \\
Eye problem & & \\
Diseases mentioned/person & 2.6 & \\
\hline
\end{tabular}


Table 2: Examples of meaning units, condensed meaning units, codes, subcategories, categories and theme from content analysis of interviews about the health-promoting program's impact on adaptation of activities.

\begin{tabular}{|c|c|c|c|c|c|c|}
\hline $\begin{array}{l}\text { Content } \\
\text { areas }\end{array}$ & Meaning units & $\begin{array}{l}\text { Condenses } \\
\text { meaning units }\end{array}$ & Codes & $\begin{array}{l}\text { Subcategori } \\
\text { es }\end{array}$ & Categories & Theme \\
\hline \multirow[t]{2}{*}{$\begin{array}{l}\text { Desire for } \\
\text { mastery }\end{array}$} & $\begin{array}{l}\text { For me it's very difficult to } \\
\text { ask for help because I want } \\
\text { to be independent... maybe } \\
\text { it's wrong... but I have a } \\
\text { need...to feel I can manage } \\
(P \text { 15). }\end{array}$ & $\begin{array}{l}\text { Difficult to ask for } \\
\text { help, wants to be } \\
\text { independent, has } \\
\text { always been. Feels a } \\
\text { need to manage. }\end{array}$ & $\begin{array}{l}\text { Wants to be } \\
\text { as } \\
\text { independent } \\
\text { as before. }\end{array}$ & $\begin{array}{l}\text { Important to be } \\
\text { independent }\end{array}$ & $\begin{array}{l}\text { (Maintain) } \\
\text { Independence }\end{array}$ & $\begin{array}{l}\text { Maintainin } \\
\text { g activities } \\
\text { of daily } \\
\text { living }\end{array}$ \\
\hline & $\begin{array}{l}\text { Sometimes you feel like they } \\
\text { think...she's old... and I don't } \\
\text { want them to think like that } \\
\text { even if I am old...because I } \\
\text { want to keep up with } \\
\text { things...I've always done that } \\
(P \text { 14). }\end{array}$ & $\begin{array}{l}\text { Doesn't want to be } \\
\text { seen as old, wants to } \\
\text { keep up, has always } \\
\text { done this. }\end{array}$ & $\begin{array}{l}\text { Wants to be } \\
\text { seen as a } \\
\text { capable } \\
\text { person. }\end{array}$ & Capable person & & \\
\hline \multirow[t]{4}{*}{$\begin{array}{l}\text { Occupational } \\
\text { environmental } \\
\text { demand for } \\
\text { mastery }\end{array}$} & $\begin{array}{l}\text { This was good because it was } \\
\text { something to go to }(P 7) \text {. } \\
\text { You've have to get ready } \\
10(P 5) \text {. }\end{array}$ & $\begin{array}{l}\text { Nice to have a goal } \\
\text { for the day, } \\
\text { something to get } \\
\text { ready and go to. }\end{array}$ & $\begin{array}{l}\text { A goal for the } \\
\text { day. Get } \\
\text { ready. }\end{array}$ & $\begin{array}{l}\text { Something to } \\
\text { go to. }\end{array}$ & $\begin{array}{l}\text { Belonging to } \\
\text { a group }\end{array}$ & \\
\hline & $\begin{array}{l}\text { It's been nice to meet...I } \\
\text { didn't know anybody...it's } \\
\text { been positive to make new } \\
\text { friendships (D 5). This } \\
\text { fellowship in the group...it's } \\
\text { been very nice (D 13). } \\
\text { It's been fantastic } \\
\text { actually...we've never talked } \\
\text { about our diseases in this } \\
\text { group (D 9). }\end{array}$ & $\begin{array}{l}\text { Never talked about } \\
\text { diseases in the } \\
\text { group. }\end{array}$ & $\begin{array}{l}\text { Way to } \\
\text { communicate. }\end{array}$ & $\begin{array}{l}\text { Communication. } \\
\text { Rules. }\end{array}$ & & \\
\hline & $\begin{array}{l}\text { You've had the possibility to } \\
\text { speak up and say what you } \\
\text { think...they've planned this } \\
\text { very well }(D 8) \text {. }\end{array}$ & $\begin{array}{l}\text { Possibility to speak } \\
\text { up and tell your } \\
\text { opinion. }\end{array}$ & $\begin{array}{l}\text { Opinions } \\
\text { were } \\
\text { requested. }\end{array}$ & $\begin{array}{l}\text { Respectful } \\
\text { encounters }\end{array}$ & Self-esteem & \\
\hline & $\begin{array}{l}\text { You've become more self- } \\
\text { confident... you've been told } \\
\text { you aren't useless even if } \\
\text { you're old (D 16). }\end{array}$ & $\begin{array}{l}\text { Not useless even if } \\
\text { old. }\end{array}$ & $\begin{array}{l}\text { Feel one's } \\
\text { value. }\end{array}$ & $\begin{array}{l}\text { Strengthened } \\
\text { self-esteem }\end{array}$ & & \\
\hline \multirow[t]{3}{*}{$\begin{array}{l}\text { Adaptive } \\
\text { response }\end{array}$} & $\begin{array}{l}\text { What Inez told us } \\
\text { yesterday...to bring the } \\
\text { telephone with you into the } \\
\text { bathroom...I've never } \\
\text { thought about that but now I } \\
\text { do it (D 14). }\end{array}$ & $\begin{array}{l}\text { Tip about bringing } \\
\text { the telephone into } \\
\text { bathroom. }\end{array}$ & $\begin{array}{l}\text { Security in } \\
\text { activities in } \\
\text { daily life. }\end{array}$ & $\begin{array}{l}\text { Increased } \\
\text { thinking about } \\
\text { security }\end{array}$ & $\begin{array}{l}\text { Change in } \\
\text { occupational } \\
\text { behaviour }\end{array}$ & \\
\hline & $\begin{array}{l}\text { About taking the bus...I used } \\
\text { to be afraid...I was very } \\
\text { afraid...the drivers don't } \\
\text { wait until you've sat } \\
\text { down... but I was told to tell } \\
\text { them to wait...so now I dare } \\
\text { to take the bus again (Pt } 15 \text { ). }\end{array}$ & $\begin{array}{l}\text { Afraid to take bus } \\
\text { before but not now. } \\
\text { Told the driver to } \\
\text { wait. }\end{array}$ & $\begin{array}{l}\text { Place } \\
\text { demands on } \\
\text { bus ride. }\end{array}$ & $\begin{array}{l}\text { Speak up about } \\
\text { one's needs }\end{array}$ & & \\
\hline & $\begin{array}{l}\text { Things you do...like making } \\
\text { breakfast and dinner and } \\
\text { going out shopping...I } \\
\text { haven't thought about those } \\
\text { as activities...they've just } \\
\text { been things you've done ( } D \\
\text { 1). }\end{array}$ & $\begin{array}{l}\text { Changing in } \\
\text { thinking about what } \\
\text { everyday activities } \\
\text { give. Not thought } \\
\text { about the daily } \\
\text { doings as activities. }\end{array}$ & $\begin{array}{l}\text { Daily doings } \\
\text { are also } \\
\text { activities. }\end{array}$ & $\begin{array}{l}\text { Insight about the } \\
\text { importance of } \\
\text { activities }\end{array}$ & $\begin{array}{l}\text { Change in } \\
\text { occupational } \\
\text { approach }\end{array}$ & \\
\hline
\end{tabular}


Table 3: Short Form Questionnaire (SF-36) scores at baseline and four-month follow-up.

\begin{tabular}{|c|c|c|c|c|c|c|}
\hline SF-36 subscales & Participants & $\begin{array}{l}\text { Baseline mean } \\
\text { (SD) }\end{array}$ & $\begin{array}{l}\text { Four-month } \\
\text { mean (SD) }\end{array}$ & $\begin{array}{l}\text { Change } \\
\text { mean (SD) }\end{array}$ & $\begin{array}{l}\text { P- } \\
\text { value }\end{array}$ & $\begin{array}{l}\text { Comp. } \\
\text { mean } \\
\text { change } \\
\text { P-value } \\
\text { (2-tailed) }\end{array}$ \\
\hline \multirow[t]{2}{*}{ Physical functioning } & Intervention $(\mathrm{n}=22)$ & $46.1(14.6)$ & $50.2(17.4)$ & $4.1(13.7)$ & .18 & .16 \\
\hline & Control $(\mathrm{n}=18)$ & $53.1(18.6)$ & $50.8(18.9)$ & $-2.3(24.4)$ & .71 & \multirow{3}{*}{.35} \\
\hline \multirow[t]{2}{*}{ Role-physical } & Intervention $(\mathrm{n}=22)$ & $77.3(40.8)$ & $63.6(39.1)$ & $-13.7(44.1)$ & .16 & \\
\hline & Control (n=18) & $45.8(42.2)$ & $48.6(33.7)$ & $2.8(43.6)$ & .79 & \\
\hline \multirow[t]{2}{*}{ Bodily pain } & Intervention $(\mathrm{n}=22)$ & $45.0(12.8)$ & $47.1(13.9)$ & $2.1(16.1)$ & .55 & \multirow[t]{2}{*}{.94} \\
\hline & Control $(n=18)$ & $55.2(28.3)$ & $56.4(27.0)$ & $1.2(22.9)$ & .82 & \\
\hline \multirow[t]{2}{*}{ General health } & Intervention $(\mathrm{n}=22)$ & $61.2(16.5)$ & $64.4(17.7)$ & $3.2(11.0)$ & .19 & \multirow[t]{2}{*}{.54} \\
\hline & Control $(n=18)$ & $66.0(20.6)$ & $64.8(20.8)$ & $-1.2(10.5)$ & .66 & \\
\hline \multirow[t]{2}{*}{ Vitality } & Intervention $(n=22)$ & $57.0(11.7)$ & $62.0(11.2)$ & $5.0(8.7)$ & .01 & \multirow[t]{2}{*}{.34} \\
\hline & Control $(\mathrm{n}=18)$ & $53.0(22.2)$ & $56.7(18.4)$ & $3.7(17.2)$ & .39 & \\
\hline \multirow[t]{2}{*}{ Social functioning } & Intervention $(\mathrm{n}=22)$ & $89.2(12.4)$ & $88.6(14.4)$ & $-0.6(12.5)$ & .83 & \multirow[t]{2}{*}{.47} \\
\hline & Control $(n=18)$ & $73.6(28.7)$ & $75.7(27.6)$ & $2.1(37.2)$ & .82 & \\
\hline \multirow[t]{2}{*}{ Role-emotional } & Intervention $(\mathrm{n}=22)$ & $83.3(36.7)$ & $74.2(43.6)$ & $-9.1(43.9)$ & .34 & \multirow[t]{2}{*}{.18} \\
\hline & Control $(n=18)$ & $70.4(41.0)$ & $81.5(32.8)$ & $11.1(30.3)$ & .14 & \\
\hline \multirow[t]{2}{*}{ Mental health } & Intervention $(\mathrm{n}=22)$ & $75.8(12.6)$ & $80.3(12.2)$ & $4.5(8.9)$ & .03 & \multirow[t]{2}{*}{.14} \\
\hline & Control $(n=18)$ & $72.2(25.5)$ & $72.9(20.7)$ & $0.7(19.6)$ & .89 & \\
\hline \multirow[t]{2}{*}{ Physical composite } & Intervention $(\mathrm{n}=22)$ & $57.4(15.8)$ & $56.3(15.4)$ & $-1.0(15.1)$ & 0.74 & \multirow[t]{2}{*}{0.82} \\
\hline & Control $(n=18)$ & $55.0(20.2)$ & $55.2(18.0)$ & $0.2(19.5)$ & 0.97 & \\
\hline \multirow[t]{2}{*}{ Mental composite } & Intervention $(\mathrm{n}=22)$ & $76.4(12.9)$ & $76.3(16.3)$ & $-0.1(14.2)$ & 0.99 & \multirow[t]{2}{*}{0.40} \\
\hline & Control $(n=18)$ & $67.3(26.5)$ & $71.7(19.2)$ & $4.4(18.4)$ & 0.33 & \\
\hline
\end{tabular}


Table 4: Life Satisfaction Index-Z (LSI-Z) and Meaningful Activity Participation Assessment (MAPA) scores at baseline and four-month follow-up.

\begin{tabular}{|c|c|c|c|c|c|c|}
\hline & Participants & $\begin{array}{l}\text { Baseline median } \\
\text { (IQR) }\end{array}$ & $\begin{array}{l}\text { Four-month median } \\
\text { (IQR) }\end{array}$ & $\begin{array}{l}\text { Change } \\
\text { median }\end{array}$ & P-value & $\begin{array}{l}\text { Comp. of } \\
\text { mean change } \\
\text { (P-value) }\end{array}$ \\
\hline \multirow[t]{2}{*}{ LSI-Z } & Intervention $(\mathrm{n}=22)$ & $45.0(41.0-48.0)$ & $44.5(39.0-50.2)$ & -0.5 & .82 & \multirow{2}{*}{.77} \\
\hline & Control $(n=18)$ & $46.0(39.0-53.5)$ & $43.0(35.5-53.0)$ & -3 & .35 & \\
\hline \multirow[t]{2}{*}{ MAPA } & Intervention $(\mathrm{n}=22)$ & $180.5(167.0-214.8)$ & $197.0(174.5-244.5)$ & 16.5 & .07 & \multirow{2}{*}{.13} \\
\hline & Control $(n=18)$ & $199.0(153.0-252.5)$ & $187.0(136.0-294.0)$ & -12 & .65 & \\
\hline
\end{tabular}

